\title{
CONSCIENCE IN ARABIC AND THE SEMANTIC HISTORY OF DAMITR
}

\begin{abstract}
Oddbjørn Leirvik
UNIVERSITY OF OSLO

With regard to research on the notion of phical works of some modern Muslim writers in Egypt, this article investigates the semantic history of the word. Classical Islamic usages are examined as well as medieval and modern Bible Arabic. The author finds that in the coining of damir as the preferred word for conscience in modern Arabic, Islamic and Christian impulses have interacted - with developments in Christian Arabic in the nineteenth century as a major influence.
\end{abstract}

The context of the current investigation into the semantics of damir is a broader analysis of the notion of conscience in the works of three modern Egyptian writers. Writing in the 1950s and 60s, the Muslim intellec-

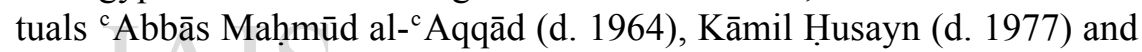
Khālid Muhammad Khālid (d. 1996) put the notion of damīr at the centre of their works about Islamic ethics, moral philosophy, and the relation between Muhammad and Christ (Leirvik 2006).

The extensive use of damir by these authors to express a uniting bond between people of different religious belongings, inspired an investigation of the semantic history of the word damir: what were the meanings of damir in classical Arabic? How and when did the word acquire the modern meaning of moral conscience?

In what follows, I will present the main findings of my historicalsemantic investigations. ${ }^{1}$ One guiding question will be the possible interaction between Islamic and Christian impulses in the coining of dami $r$ as the preferred word for 'conscience' in modern Arabic. My semantic investigation will rely partly on lexicographical evidence. Dictionaries summarise the evidence of a specific textual corpus at a given time, not as neutral observations, but as definitional efforts in their own right. In the case of dictionaries from European languages into Arabic, entries may even function as innovative suggestions.

1 In my work on the semantic history and current meanings of damīr, Michael Carter, who was co-supervisor for my doctoral project, provided valuable and much appreciated advice regarding the classical Arabic sources. I would therefore like to dedicate this article to Michael Carter, wishing him well on his 70th birthday in 2009. 
A second focus will be on Arabic bibles, from early medieval manuscripts to modern printed versions, with the purpose of elucidating how al-damì became the preferred term for rendering the Greek syneidessis and its cognate words in Syriac, Coptic and Latin.

'Conscience' in the modern Arabic lexicon

In Modern Standard Arabic, $\breve{s} u^{c} \bar{u} r$ and $w a^{c} y$ are the words mainly used for self-reflexive consciousness (Wehr 1979, 554 and 1268). Given the oscillation between self-reflexive consciousness and moral conscience in some European languages (such as French), one cannot preclude that dami $r$, in its modern usage as the preferred word for conscience, may also connote self-consciousness in a wider sense.

For moral consciousness or conscience, as distinct from consciousness in a general sense, a modern English-Arabic dictionary gives two alternatives: damīr and wijdān (Doniach 1982, 75). Correspondingly in modern Arabic translations of the World Declaration of Human Rights, damir alternates with wijdān. ${ }^{2}$ More than damir with its reference to inner thoughts, wijdān seems also to connote experience and emotion, also when used in the possible sense of moral consciousness/conscience. ${ }^{3}$

Other words for conscience in the modern Arabic lexicon include dimma and sarīra. Both Belot's French-Arabic dictionary from 1890 and Spiro's English-Arabic dictionary of colloquial Egyptian Arabic from 1897 has dimma as the first entry and damīr the second. ${ }^{4}$ Saadeh's

2 The Arabic version that is available on the UN website www.unhchr.ch/udhr/lang/arz.htm (accessed 5 Jan 08) has damīr in all cases. A different version, supplied by the Cairo Institute of Human Rights Studies in December 1997 has damīr in the preamble, but wijdān in art. 1 and 18.

3 In some modern English-Arabic dictionaries, such as Saadeh (1911) and Doniach (1982), wijdān is listed as the second option after damīr for 'conscience'. However, neither Wehr's Standard Arabic-English Dictionary nor Badawi and Hind's Dictionary of Modern Egyptian Arabic (1986) include 'conscience' among the suggested translations of wijdān. As for earlier evidences, neither Freytag (1835) nor Lane (1874) have any entry for wijdān. But alBustān̄̄'s Kitāb muḥ̣̂t al-muḥ̣̂t (1867-70) does have an entry. He explains that among the Șūfis, wijdān designates encounter with God (mușādafat al-haqq $\left.t^{c} \bar{a} l \bar{a}\right)$, whereas in other well-known usages, it stands for 'the soul and its inner forces'.

4 The use of dimma ('protection') might be emphasising the binding aspect of conscience, which some users of Modern Arabic may have regarded as not sufficiently covered by damīr. As noted already by Humbert (1838, 249), dimma (dimma) was early used in Egyptian colloquial Arabic for conscience - 
dictionary (1911) has sarīra as its third entry for 'conscience'. As a cognate of sirr, sarra would be expected to underline the inner, nondivulged character of conscience.

The dominant rendering of conscience in Modern Standard Arabic, however, is damīr for which Wehr lists the following meanings: 'heart; mind; innermost; conscience; (independent or suffixed) personal pronoun' (Wehr 1979, 637). Etymologically, damīr refers to the hidden. In the coining of damir as a word for conscience in modern Arabic, etymology therefore indicates a strong inward orientation, towards a moral voice within. The use of damir (or even ism mudmar) for the personal pronoun in Arabic grammar may point in the same direction: the personal pronoun conceals the agent, who devoid of his name has 'shrunk' into anonymity. ${ }^{5}$

Proceeding to modern Egyptian colloquial Arabic, we find that Badawi and Hinds render damìr as '1. conscience. 2. [gram] pronoun' For wijdān or wigdān, they list '(inner) consciousness, imagination, mind'. (Badawi and Hinds 1986, 524).

The philosophical dictionary compiled by the Christian Arab, Jamāl Șalībā, which concentrates on French and Arabic philosophical terminology, translates $\check{s}^{c} \bar{u} r$ as 'conscience psychologique', and damir as 'conscience morale'. First, Salībā defines damīr as a disposition of the soul to distinguish between good and bad deeds, accompanied by the faculty to issue immediate moral judgements on the value of individual actions. Secondly, he cites Rousseau in order to show that conscienceas a 'divine instinct' - can also be conceived of as capable of issuing moral judgements in advance; functioning both as a guide and a restraint (Șalībā 1971, 763).

\section{Damīr in classical and medieval Arabic}

The word damī is not found either in the Qur ${ }^{\circ} \bar{a}$ or in the hadith collections. Among Muslim writers of classical and medieval Arabic, the word does occur. But in pre-modern contexts, there is no evidence that was ever used in the specific sense of moral consciousness or conscience. What we do find is the following: damīr in the grammatical meaning of pronoun; damīr in the general sense of hidden, innermost thought (often interchangeable with sirr or sarira); and what seems to be a typical Șūfĩ distinction between

\footnotetext{
as an alternative to damīr.

5 According to Wehr, the first form of the verb damara means 'to be or become lean, emaciated ...' or 'to contract, shrink'.
} 
as 'the inner unconscious'.

\section{Grammar and logical theory}

A firmly established use of damīr is found in Classical Arabic grammar, where damir has carried the meaning of 'personal pronoun' from the second Islamic century onwards. By use of damir, the hidden, nonexpressed aspect of the pronoun is emphasised, more than its function as a 'pro-noun' (i.e. replacing the noun) in grammars within the Latin tradition (Carter 1981, 250f).

It is interesting to note that in a discussion of al-Mubarrad's refutation of the great grammarian, Sībawayhi, al-Mubarrad is accused by Ibn Wallād of having made up something in his own mind (iddi ${ }^{c} \bar{a}^{\supset} u n{ }^{c}$ ala damīrihi) without any support in Sībawayhi's text (fì nașși qawlihi). What is merely in the damīr, may also be contested (Carter 2001, 59f).

\section{Shīcite usage}

In the mystical commentary on the Qur ān attributed to the Shī' ite Imām $\mathrm{Ja}^{\mathrm{c}}$ far al-Șādiq (d. 765), one finds a reference to damìr in his explanation of Qur ${ }^{\top} \bar{a}$ n 28:10. This verse employs two different words for 'heart': $f u^{\circ} \bar{a} d$ and qalb. Al-Saadiq's commentary adds other words for the interior of the human being, and runs as follows (in my translation):

The $s a d r$ is the source $\left(m a^{c} d i n\right)$ of submission, the qalb is the source of certitude, the $f u$ ' $\bar{a} d$ is the source of contemplation, al-dami $\bar{r}$ is the source of the secret (al-sirr, i.e. things known only to God), and the soul (nafs) is the refuge of all good and all evil. ${ }^{6}$

Among the words listed by al-Șādiq for the inner sources of the human being, damīr is the only one which does not occur in the Qur ${ }^{\top} \bar{a}$. As one can see, it is identified with, or at least intimately related to sirr.

Also in the collection of Imām ' Alî̀'s sermons, which were edited in their present form in Nahj al-baläga in the eleventh century, one finds references to dami $r$ in the sense of the inner self. In an intriguing passage from one of his sermons, ${ }^{\mathrm{c}} \mathrm{Al} \overline{\mathrm{i}}$ speaks of the $\operatorname{dam} \bar{a}^{\mathrm{D}}$ ir of human beings as 'God's eyes'. After having assured his audience that nothing is hidden from God of whatever people do by day or night, he says:

Your limbs are a witness, the organs of your body constitute an army (against yourself), your inner self serves Him as eyes (to watch your sins; wadamä $\bar{a}^{\mathrm{irukum}}{ }^{\mathrm{c}}$ uyūnuhu) and your loneliness is open to Him'. ${ }^{7}$

\footnotetext{
6 Nwyia 1968, 215.

${ }^{7}$ Imam Ali 1986, 411 (sermon 198), translating ${ }^{\mathrm{c}} \mathrm{Al}$ ī 1963, 394.
} 
In one of his sayings, he states that if a person is too eager to acquire the riches of the world, then it fills his damir with distress which keeps altering in 'the black part of his heart', some grief worrying him and other giving him pain. ${ }^{8}$

The use of damīr in Nahj al-baläga is not necessarily very precise. As a reference to the inner, invisible self, damir often seems to be interchangeable with sarìra. A parallel in the opening of one of ${ }^{\mathrm{c}}$ Alī's sermons, however, might indicate than there could be more to it than mere synonymy: 'Allāh knows hidden matters (al-sarä'ir) and is aware of inner feelings (al-damāo $\left.\bar{a}^{\supset}\right)^{\prime} .{ }^{9}$

\section{Șüfì usage}

It might be that these passages attributed to ${ }^{c} \mathrm{Al}$ i should be read in the light of later Süfì usage, in which some interpreters do find a rather elaborate distinction between find a very pointed usage in which damir denotes the inner conscious, whereas sirr stands for the inner unconscious. According to Louis Massignon, this distinction can already be traced in the works al-Hallāj (d. 922). Massignon gives thirteen references (Massignon 1954, 29), and translates damīr as used by al-Ḥallāj as 'le moi conscient de l'homme (opp. sirr, son inconscient profond)'.$^{10}$

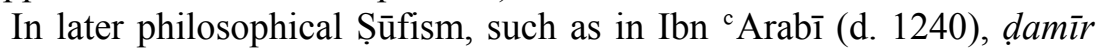
seems to have been used in the same way - signifying the conscious self and contrasting sirr, the deep unconscious. In Ibn 'Arabī's meditation on the metaphor of travel and the ecstatic night journey of the Prophet, he writes (in my translation):

He experienced a divine gift and a special care, something that had not arisen in his heart (bi-sirrihi; in his inner unconscious) or been unfolded in his conscious reflection, ( $F \bar{l}$ damìrihi, Ibn ${ }^{\mathrm{C}}$ Arabi 1994, 24).

In earlier stages of Sufism, al-Muhāasibī (d. 857) employed the notion of $\underline{d a m \bar{\imath} r}$ in the context of his spiritual technique of muhāsaba or selfexamination. However, his use of damir and sirr appears not to be influenced by the more elaborate Șūfĩ usage referred to above. Damīr and sirr are instead used to distinguish the inner from the outer in a more general

\footnotetext{
8 cAlī 1963, 639 (saying 377), cf. Imam Ali 1986, 656.

${ }^{9}$ Imam Ali 1986: 215, translating ${ }^{\mathrm{c}}$ Alī 1963, 151 (sermon 85).

10 This is also the meaning of damīr given by the Arabic-French Șūĩ dictionary $A l-M u^{c} j a m$ al-süfi, which-in tune with Massignon-defines damīr as 'Le moi conscient de l'homme' in contrast to sirr which means 'Inconscient profond de l'homme' (Ibn 'A Abd Allāh n.d., 23).
} 
sense. For example, he distinguishes between pious fear $(\operatorname{taq} w \bar{a})$ at the level of the limbs and at the level of damīr (al-Muhāsibī 1940, 9, cf. 11, 13). He employs the notion of sirr with a similar distinction, namely that between self-examination and taqwā on the secret (sirr) and overt ('alāniyya) levels respectively (ibid., 6f, cf. 133).

In al-Ghazālī's Revival of the Religious Sciences, the term damīr refers to secret, inner thoughts (al-Ghazālī 1927, 3: 22). In his work 'The Beginning of Guidance', it has possibly mystical overtones too, when he states that 'God most high is aware of your secret being' (damīr, alGhazāli 1950, 4). He seems to equate damīr with sarìra and states elsewhere in the same work: 'God most high is aware of your inmost thoughts (sarīra) and sees your heart' (qalb; ibid., 19).

\section{Philosophical usage}

In medieval Arabic, fine distinctions between damīr and sirr may have been restricted to Șūfì usage. As for philosophical use of damīr the word seems mostly to be used in the general sense of inner thoughts. For example, al-Fārābi speaks of the externalism of the voice which gives expression to what is otherwise concealed in the mind (al-damir , quoted by Amīn 1964, 149).

Other Muslim philosophers from the classical period used damīr with reference to heartfelt relations or inner thoughts, but with no apparent mystic or moral connotations. In a text originating from the philosophical circle of Abū Sulaymān al-Sijistānī (d. 985), we find the following statement attributed to Abū Sulaymān:

If the heart (damir) of one friend is open to another, the truth glows between them, the good enfolds them, and each becomes a mainstay to his companion, a helpmate in his endeavor, and a potent factor in his attaining his wish. There is nothing surprising in this: souls ignite one another, tongues exchange confidences; and the mysteries of this human being, a microcosm in this macrocosm, abound and spread (Kraemer 1986, 163).

From a later period, in a work of the theologian and philosopher Sayf al-Dīn al-Āmidī (d. 1233) entitled $A l^{-}{ }^{\circ} I h k a \bar{m}$ fì ${ }^{\circ} u s ̦ \bar{u} l a l^{\circ} a h k a \bar{m}$, one can find the following statement (in Michael Carter's translation):

Nor do we accept that the understanding [of the meaning of words] can only be achieved by historical transmission [of words with that meaning]: what about pedagogical transmission, such as is done with children, or the deaf and dumb use of sign language to make known to others what is in one's mind (damîrihi)?' (al- Āmidī 1985, 1: 34).

A more specialised usage, related to logical theory, can be found in Ibn 
Sīnā (d. 1037). In his logical theory, inspired by Aristotle, he uses damīr to explain a special kind of deduction or syllogism (qiyās) which conceals its major premise: 'Damīr is a syllogism, the major premise of which is hidden' (Șalībā 1971, 764).

Damīr in early dictionaries, Arabic and Western

In Arabic dictionaries from before the modern period, one finds that damì invariably stands for what is concealed in one's heart. Unlike Șūfì usages, damīr tends to be identified with sirr. The famous Lisān al- ${ }^{c}$ arab which was compiled by Ibn Manzūr (d. 1311) defines damīr as al-sirr, as inner thought, or as the thing that you conceal in your heart. ${ }^{11}$

Several centuries later, the Arab lexicographical tradition reached its peak with the gigantic Tāj al- ${ }^{c} a r \bar{u} s$ which was compiled by al-Zabīīi (d. 1791). Its definition of $\frac{d a m i \bar{r}}{}$ is substantially identical with that given by Lisān al- ${ }^{c}$ arab (al-Zabīdī 1888, 3: 352).

Turning to the first dictionary of the Arabic language to be edited and printed in the West, the Lexicon Arabicum by F. Raphelengius (1613), we find that this particular dictionary defines damīr as 'sensus, conscientia'. The added Latin index gives three different entries for conscientia, viz. damīr, dihn and niyya. Given the fact that in European languages, there was hardly any distinction between 'conscience' and 'consciousness' until the seventeenth century, it is hard to decide whether conscientia in this context is meant to connote moral consciousness, or merely refers to consciousness in general.

Raphelengius' dictionary was published posthumously by the Dutch scholar, Thomas Erpenius, who was also responsible for the first printed edition of the New Testament in Arabic, published in Leiden in 1616. At the beginning of the seventeenth century, the Netherlands were still under Spanish domination, and there is evidence that Thomas Erpenius was acquainted with Moriscos of Spanish origin (van Koningsveld 1997, 32 6, 195f). This suggests that Erpenius and Raphelengius had HispanoArabic as a major linguistic source on which to draw. One of the sources probably utilised by Raphelengius was a manuscript of Spanish Mozarabic origin known as 'The Latin-Arabic Glossary of the Leiden University Library', which may be as old as the twelfth century. For conscientia, it lists the following Arabic equivalents: damīr wa-niyya wa-dihn (Seybold 1900, 99). As can be seen, the entries are identical with those of Raphelengius. The glossary in question may stand as intriguing evidence of a medieval Arabic rendering of conscientia as damīr. How-

11 Ibn Manzūur, Lisān al- ${ }^{c}$ arab. 1955, 4: 492. 
ever, this Hispano-Arabic usage seems to have had no major impact either on Oriental Christian Arabic or on Islamic Arabic in the medieval period.

Damīr as moral consciousness: since when?

So since when can one find damir used in the sense of 'moral consciousness/conscience' in modern Standard Arabic and Egyptian colloquial Arabic?

Most Western dictionaries from the nineteenth century are orientated towards Classical Arabic. None of them indicates that damir should be taken in the sense of moral consciousness/conscience. Neither Freytag's Lexicon Arabico-Latinum (1835) nor Lane's Arabic-English Lexicon from 1874 include 'conscience' among the meanings of damīr - only variations on the theme of 'secret thought'. For the indefinite sense, Lane listed the following meanings: 'a thing that thou concealest, or conceivest, or determinest upon...in thy heart, or mind:...a secret; syn. sirr'. Hence, he notes, it is also used as meaning a pronoun. As for the definite sense, he informs that al-damìr may also signify 'The heart [itself]; the mind; the recesses of the mind; the secret thoughts; or the soul' (Lane 1874, 1/5: 1803).

The contemporary 1875 edition of the Dictionnaire arabe-français by A. de Biberstein Kazimirski gives similar evidence. His dictionary does not include 'conscience' among the mind-related meanings of damir only spirit, heart, intimate and covert thought at the bottom of the heart (Kazimirski 1875, 3: 46). One may thus conclude that the dictionaries of Freytag, Lane and Kazimirski all reflect traditional Arabic and classical Șüfĩ usage, in which damīr designates innermost, secret thoughts or the hidden conscious.

There are, however, other nineteenth-century dictionaries, even from the first half of the nineteenth century, which indicate that damir could also be taken in the sense of 'moral consciousness'. These dictionaries also reflect contemporary and colloquial usage. In a chapter concerning 'défauts' in Guide de la conversation arabe from 1838, Jean Humbert suggests that 'conscience' might be rendered either as damīr or dimma/dimma (Humbert 1838, 249). Humbert clearly has 'conscience' in the sense of moral conscience in mind, since he also lists some Arabic expressions for remorse: $n a k h z=n a k h z$ al-damì $={ }^{c} a \underline{d} \bar{a} b$ al-damìr .

Significantly, dictionaries linked to a Christian Arab context and originating from the same period, give similar evidence. An early testimony which corroborates Humbert's suggestion can be found in a French-Arabic dictionary which was compiled by the Egyptian Copt 
Ellious Bocthor, and published in 1828-29 after having been revised and expanded by A. Caussin de Perceval. For 'conscience' in the sense of 'sentiment intérieur du bien et du mal', Bocthor/Perceval first lists dimma, then damīr and as a third option sarīra (Bocthor 1828-29, 1: 189).

Another nineteenth-century Christian Arab suggestion that damīr can also be used in the sense of moral consciousness is found in Kitāb muhìt al-muhīt, the famous dictionary of Butrus al-Bustānī which was published in Beirut in two volumes in 1867-70. Al-Bustānī, who was a Maronite but later became a Protestant, was strongly involved in the translation work which resulted in the so-called Bustānī-van Dyck Bible. The dictionary's relevant entry under al-damir is as follows (in my translation):

... and the secret (al-sirr), and the innermost thought (däkhil al-khātir); and hence al-damir in the sense of the created ability in the human being to distinguish between what he is permitted to do and not do; or an inner feeling which informs about the lawful and the illicit, forbidding the latter (al-Bustāni n.d./1870, 1255).

As we shall see, Arabic bibles from 1860 onwards corroborate Bocthor's and al-Bustānī's lexicographical novelties. The combined evidence indicates that in the nineteenth century, damir was given the meaning of 'moral consciousness' and 'conscience' in both Christian Arabic usage and French-Arabic lexicographical efforts. This seems to have happened in both the Egyptian (Bocthor) and Syrian-Lebanese (al-Bustānī) contexts, with translation work between French and Arabic as a possible trigger (Humbert, Bocthor).

Towards the turn of the century, we find similar evidence in dictionaries of Egyptian colloquial Arabic. Socrates Spiro's ArabicEnglish dictionary from 1895 renders damīr as 'conscience, mind', and his English-Arabic dictionary from 1897 translates 'conscience' as (1) dimma and (2) damīr (Spiro 1974/1897, 139; 1980/1895, 353).

From the beginning of the twentieth century, one regularly finds damir in the sense of 'conscience' in dictionaries of modern Standard Arabic. In Saadeh's English-Arabic Dictionary from 1911, published in Cairo, 'conscience' is rendered as (alternatively) damīr, wijdān, 'idrāk, $n u t q^{c}$ 'aqli - whereas 'consciousness' is rendered as wijdān, $\check{s} u^{c} \bar{u} r,{ }^{\circ} i d r \bar{a} k$ and da âkira (Saadeh 1911, 369). The combined lists may testify to a certain oscillation in some Arabic words between 'conscience' and 'consciousness', perhaps reflecting the corresponding ambiguity in European languages. 
At the time of Saadeh's dictionary, the Encyclopaedia of Religion and Ethics stated that 'the modern Islāmic languages employ conventional translations of the European words [for conscience]; in Turkish vijdan (properly 'sensation') is employed, in Arabic damīr ('the hidden being')' (Margoliouth 1964/1911, 4: 46). ${ }^{12}$

\section{Damīr in biblical Arabic}

Editing work on Arabic bible translations from the early Middle Ages has been limited and they are difficult to overview.

When searching for Arabic renderings of New Testament verses in which syneidèsis - the Greek word for conscience-occurs, it must be kept in mind that most Arabic translations from the ninth until the nineteenth century were made from versions in other languages than Greek, namely from the Syriac Peshitta, ${ }^{13}$ the Latin Vulgate or from Coptic. Thus, one cannot necessarily say that this, or that Arabic word, is a translation of the Greek syneidèsis. In Coptic, however, suneidesis is used as a loan-word from Greek. As for the versions based upon the Latin Vulgate, the Arabic words that are used translate and interpret conscientia.

In the following section, I will examine the vocabulary used in the relevant verses in the Epistles of the New Testament (27 occurrences), the Acts of the Apostles ( 2 occurrences), and a variant reading of John 8: 9 which includes the word syneidesis.

When investigating Arabic bible manuscripts from the pre-modern period, it turns out that dami $r$ has in fact not been the preferred word for syneidèsis and related words in other languages. Instead, either niyya ('intention') or the word bașira ('clear evidence', 'insight') prevails. Damī is preferred in one single tradition, namely Hispano-Arabic bible translations that may date from as far back as the tenth century.

\footnotetext{
12 William Tisdall, writing in 1906, contended that the Arabic language does not have any word which 'properly expresses what we mean by conscience'. It is obvious, however, that $\frac{d a m \bar{i} r}{r}$ was already in the picture, since he qualifies his assertion by recording that 'in Arabic and Persian we have to use damir (the heart, the mind), but even this does not occur in the Qur'ân'. (Tisdall 1906, 62f)

13 The Syriac Peshitta (Bible 1979), on which many of the oldest Arabic translations depend, renders syneídēsis as tirtå in all cases except two. In Romans 9: 1 and 2. Cor. 1: 12, reycåna (mind) is used instead. In Titus 1: 5, rey $^{c}$ ånå is used together with tirtå. In 2. Cor. 5: 11, mada $a^{c}$ is used. I am thankful to Elie Dib Wardini, my former colleague at the University of Oslo, for assistance with the Peshitta references.
} 
Medieval and early modern Arabic bibles ${ }^{14}$

In early medieval manuscripts originating from monasteries in Palestine and Sinai, niyya was the most common choice. Three Sinai Arabic manuscripts from the ninth century containing translations from Syriac or Greek all testify to the prevalence of niyya in the south Palestinian tradition. Sinai arab. 151, 154 and 15515 all have niyya in the vast majority of cases. But Sinai arab. 151 has 'aql ('mind') in two places where the Syriac Peshitta also has different options. Similar evidence is found in a Tischendorf-related Arabic manuscript from 892. ${ }^{16}$ The codex, referred to by Tischendorf as arpet, has niyya in six legible cases, and $r a^{3} y$ ('opinion') in three.

From the period between the ninth and fifteenth centuries, only a few Arabic bible manuscripts are available. As regards bible translations from the Hispano-Arabic context, a 1542-43 New Testament manuscript kept in Madrid, parts of which might go back to the tenth century, distinguishes itself by its unique preference for damīr (BNM cod. 4971). Together with the lexicographical testimonies cited above from the twelfth-century Latin-Arabic glossary of Mozarabic origin and the Lexicon Arabicum from 1613, which was probably also influenced by Hispano-Arabic, the Madrid manuscript testifies to a medieval Christian Arabic use of damīr in the sense of moral consciousness.

As for other medieval and early modern manuscripts, MS Vat. copt. 9 (dated 1204/5) contains an Arabic version accompanying the CopticBohairic text, but with additions from both Greek and Syriac sources. According to Thompson, this eclectic recension, which is sometimes called the 'Egyptian Vulgate', dates back as far as the tenth century. It became generally used by the thirteenth century, not only in Egypt, but also in Syria (Thompson 1955, 10). Its version of the Gospels was reworked by the Alexandrian scholar, Hibat Allāh ibn al- ${ }^{\mathrm{c}}$ Assāl, resulting in the so-called 'Alexandrian Vulgate', which according to Metzger, became a source of linguistic corruption and formed the basis of all printed editions of the Arabic Gospels from the editio princeps of 1591 until the twentieth century (Metzger 1977, 264f).

In connection with the European Renaissance and Catholic missionary efforts, printed Arabic bibles began to appear in various contexts. In 1591, the Medicean printing house in Rome published the first printed

\footnotetext{
14 For more details regarding the translation of individual verses in the New Testament, see Leirvik 2006, 73-77, 254-257.

15 Edited by Staal 1983-4, Gibson 1899 and Gibson 1894 respectively.

16 Edited by Stenij 1901.
} 
version of the Gospels in Arabic, basing itself mainly on the MS Vat. copt. 9. As for the rendering of syneidesis in Acts and the Epistles, we shall see that two major tendencies can be identified in subsequent editions of the New Testament and the Bible. One is represented by the editio princeps of the New Testament (Leiden 1616) and of the Bible (Rome 1671) in Arabic, the other by the Polyglot Bibles of the seventeenth century. The first tendency prefers niyya, but includes damir in some cases. The second tendency opts for bașìra.

In 1616, Thomas Erpenius in Leiden published the first printed edition of the entire New Testament in Arabic (Bible 1616). As we have seen, Erpenius was also involved in a lexicographical work which was partly influenced by Hispano-Arabic/Mozarabic, the linguistic tradition in which the medieval use of damir for conscientia is attested by both dictionaries and a New Testament manuscript. As for the rendering of syneidèsis in Erpenius' Arabic New Testament, however, the preferred option was not damir . Instead, niyya is used in the majority of cases, although he does prefer (or add) damī in six of the relevant verses. ${ }^{17}$

In 1671, following the final union between Rome and the Arabicspeaking Maronites in the sixteenth century, Congregatio de Propaganda Fide printed the first edition of the entire bible in Arabic - based on the work of Maronite Christians. This so-called 'Propaganda Version' conformed to the Latin Vulgate, but was partly based on previous Arabic manuscripts of Syrian and Coptic origin. Like Erpenius' New Testament, the Propaganda Version has niyya in nearly all places, with the same exceptions for damir as in Erpenius (Bible 1822/1671).

In the same period, Arabic versions of the Bible were included in both the Paris and London Polyglot Bibles, completed in 1645 and 1657 respectively. The editor of the Paris Polyglot put a Maronite scholar, Gabriel Sionita, in charge of editing the Arabic text. The scholars based

17 The verses that have damīr instead of niyya (2. Cor. 1: 12, 4: 2 and 5: 11, in Romans 9: 1, and-together with niyya-in Romans 2: 15 and Titus 1: 15) correspond more or less to the verses that reveal other options than the standard choice of tirtå in the Syriac Peshitta (cf. note 10 above).

A manuscript of Egyptian/Coptic origin, possibly from the sixteenth century, has niyya in all places except bar two. Corinthians - where it has damīr. As one can see, the evidence conforms partly to that of Thomas Erpenius' printed New Testament in Arabic from 1616. The manuscript is found in the un-catalogued collection of the Evangelical Theological Seminary in Cairo. It has not been edited, and the dating is a guess. I am grateful to Mark Swanson for drawing my attention to the manuscript. 
their work on a variety of manuscripts, which as far as the Gospels were concerned, were mostly in accordance with the aforementioned 'Egyptian Vulgate'. As for the rest of the New Testament - that is to say, the most relevant parts for the present investigation - the source appears to have been a different one, namely an Arabic manuscript translated from Greek and brought from Aleppo by the Carmelite Father Joseph (Graf 1975-77/1944-53, 1: 93f).

In all Arabic bible editions within this tradition, there is a preference for the word bașira ('insight'). The London Polyglot was edited by Brian Walton, and depends on the Paris Polyglot for the Arabic version. It has bașira ('insight') corresponding to syneídesis in most of the verses in question, but a wide variety of alternative renderings in other verses (Bible 1657).

In 1727, a translation of the New Testament by the Syrian Salomon Negri was published in London (Bible 1727). According to Graf, the translator keeps close to a Melchite recension of 'the Egyptian Vulgate', but reworks it from Greek. As for the rendering of syneidēsis, this version comes close to the Polyglots and opts for bașira ('insight') in all places except one.

Damīr in modern Arabic bible editions

From the latter part of the nineteenth century, a variety of modern Arabic bible translations have been produced and used by the churches in the Middle East.

In the 1840s, American missionaries in Syria initiated a new Arabic translation, which came to be known as the Bustāni-van Dyck or the Smith-van Dyck Bible (Bible 1991/1865). ${ }^{18}$ The New Testament was published in 1860, followed by the edition of the entire bible in 1865. In 1878, a Catholic initiative resulted in a different version of the New Testament, which is now conventionally referred to as the old Jesuit Bible (Bible 1992/1878).

In 1857, shortly before the Bustāni-van Dyck version, a new Arabic translation was published by the 'Society for the Propagation of Christian Knowledge' in London. The translation work was headed by the Lebanese Christian. Fāris al-Shidyāq (Bible 1983/1857). ${ }^{19}$ In rendering syneidesis, the Shidyāq version keeps close to the tradition from Erpenius. It has niyya in most cases, but (similar to Erpenius) has damīr

18 The work which resulted in the Bustānī-van Dyck version was initially headed by Eli Smith.

19 The New Testament was published in 1851, and the entire Bible in 1857. 
in six. ${ }^{20}$

Then, with the bible edition which carries the name of Butrus alBustānī (the author of Kitāb muhīt al-muhìt, cf. above), comes the change. Contrary to prevailing practices in Arabic bible translations till then, the translation team took the decision to let damir render syneídēsis. In all relevant verses, the Bustānī-van Dyck Bible makes use

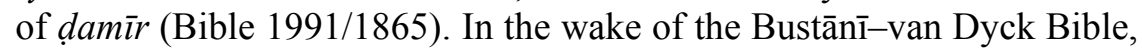
the Jesuits made the same decision (Bible 1992/1878).

The Bustāni-van Dyck translation was based entirely on Hebrew and Greek manuscripts. The linguistic ambition was to conform to living Arabic and it is generally regarded as a landmark in modern Arabic bible translation. According to the Bible Society in Egypt, this version has remained by far the most widespread bible translation in Egypt - among Catholics and Protestants as well as Copts . It has often been described as 'the book of the people'. It is also the version commonly used for liturgical readings in Egyptian churches. Moreover, this would be the bible edition most often referred to by Egyptian Muslims. ${ }^{21}$

There are strong indications, therefore, that Bible Arabic was one of the main factors in the process towards a general use of damir for moral consciousness/conscience in Modern Standard Arabic and in Egyptian Arabic usage more specifically. It at least seems highly probable that Bible Arabic has contributed towards the semantic and conceptual development which was taken a step further when reform-minded Egyptian intellectuals (Muslims as well as Christians) such as Farah Anțūn, M. H. Haykal and Ahmad Amīn employed damīr (or wijdān) when rendering 'conscience' in their reception of European philosophy and in their modern elaborations on Christian or Islamic ethics (Leirvik 2006, 83-89).

\section{Conclusion}

The variety of words used for rendering 'conscience' in Arabic, triggers the question of what is really at stake in this semantic process: is it the European notion of 'conscience' that is translated into Arabic by use of several words covering different aspects of the received notion? Or are we instead faced with a number of Arabic words that gradually acquire new meanings when - in a modern context - the need is felt more strongly than before to express a concern for personal integrity and faith-

\footnotetext{
${ }^{20}$ Differently from Erpenius, it has damīr in John 8: 9 and bașîra (insight) in 1. Cor. 8: 7 and 8: 10 .

${ }^{21}$ According to officials in The Bible Society in Egypt (personal communication, December 1997).
} 
transcending moral obligation? Probably, the process went both ways. As for the different words that may have been considered as candidates, it is clear that during the twentieth century, al-damir has become the standard word for translating 'conscience' as well as for expressing the modern Arabic (Islamic-Arabic as well as Christian-Arabic) notion of 'conscience'. 22

Classical Arabic and the Islamic tradition gives the modern Arabic notion of al-damir other emphases over and above those found in European terms for 'conscience'. It is resonant with an etymology and a spiritual tradition, notably Șufissm, which consistently turns the attention inwards.

As a general conclusion to my lexicographical and semantic considerations, I would suggest that Christian Arabic has been a major influence behind the modern Arabic (even Islamic) coining of al-damir as moral consciousness or conscience.

As regards the relation between etymology and the pragmatics of language, we have seen that the word damir points unequivocally in the direction of something known intimately by oneself, as innermost knowledge. Pragmatically, in the way twentieth-century Egyptian writers employ the word damir , there may still be a most important communal dimension to it in the sense of a faith-transcending, moral obligation.

We have seen that in Christian Arabic in Spain, there is both lexicographical and bible manuscript evidence that damir could be used for conscientia/syneídesis in the medieval period - in a context marked by relatively intense close and sustained Muslim-Christian interaction. It seems, however, that medieval Mozarabic usage remained a marginal voice, with no strong impact on the Arabic-speaking community or written Arabic in general.

As for Christian and biblical Arabic in the nineteenth and twentieth centuries, the evidence is more conclusive: here lies a major source of the semantic development that traced above. Indeed, translations of European philosophy into Arabic in the beginning of the twentieth century may have contributed in the same direction (Leirvik 2006, 82-87).

It was this semantic and intellectual development that culminated in the 1950s and 60s when al- ${ }^{\mathrm{c}}$ Aqqād, Husayn and Khālid put al-damīr at the centre of their innovative approaches to Christ, Muhammad and the

22 Damīr has also left its marks in languages influenced by Arabic. In contemporary Urdu, conscience is zamīr (written like the Arabic damīr); in Swahili, it is dhamiri. In Turkish, however, the common word for conscience is vicdan (cf. the Arabic wijdān). 
shared Muslim-Christian heritage. When, for instance, al- ${ }^{\mathrm{A}}$ Aqqād, in his groundbreaking work, 'Abqariyyat al-Masīh (The Genius of Christ, 1953), speaks of 'the law of love and conscience' (šarī at al-hubb wa-ldamir), his summary of the perceived essentials of Christ's teachings is simultaneously taken as an inspiration for modern reform of Islamic ethics. In a similar vein, Khālid in his book $\mathrm{Ma}^{c} a{ }^{c}$ ala al-tarīq. Muhammad wa-l-Masīh (Together on the Road: Muhammad and Christ, 1958), speaks of the integrity of human conscience as the uniting bond between the two prophets and their adherents (Leirvik 2006, 2008).

In this way, the word dīmì became-for a period that is already history- a point of crystallization for linguistic and intellectual interaction between Muslims and Christians.

\section{REFERENCES}

Ibn ${ }^{\mathrm{c}} \mathrm{Abd}$ Allāh, ${ }^{\mathrm{c}} \mathrm{Abd}$ al- ${ }^{\mathrm{c}} \mathrm{Azīz}$. n.d., Al-Mu ${ }^{\mathrm{c}} \mathrm{jam}$ al-Șūfĩ. ${ }^{\mathrm{c}}$ Arabī-faransī. Offprint from Al-Lisān al- ${ }^{c}$ Arabì.

cAlī ibn Abī Țālib. 1963. Nahj al-balāğa. Beirut: Dār al-Andalūs.

(Imam) Ali ibn Abu Talib. 1986. Peak of Eloquence. Nahjul Balagha. Sermons, Letters and Sayings of Imam Ali ibn Abu Talib, trans. Sayed Ali Reza. NewYork: Tahrike Tarsile Quran.

al-Āmidī, Sayf al-Dīn. 1985. Al-Iḥkām fì ${ }^{\circ} u s ̣ u ̄ l ~ a l-a h k a \bar{m}$, ed. Ibrāhīm al${ }^{c}$ Ajūz, 2 vols, Beirut: Dār al-kutub al-' ${ }^{c}$ ilmiyya.

Amīn, 'Uthmān. 1964. Al-Juwwāniyya. ${ }^{\circ} U s ̦ \bar{u} l{ }^{c}$ aqūda wa-falsafa țawra. Beirut: Dār al-qalam.

Ibn Arabi. 1994. Le Dévoilement des effets du voyage. Al- ${ }^{\top} I s f a ̄ r r ~ c a n$ natā ${ }^{\supset} i j$ al- ${ }^{\supset}$ asfār. Texte arabe établi, traduit et présenté par Denis Gril. Paris: Éditions de l'Éclat.

Badawi, El-Said, and Martin Hinds. 1986. A Dictionary of Egyptian Arabic. Arabic-English. Beirut: Librairie du Liban.

Belot, P. J.-B. 1890. Dictionnaire français-arabe, 2 vols, Beirut: Imprimerie Catholique.

Bible. 1616. Novum D. N. Jesu Christi Testamentum Arabice. Ex Bibliotheca Leidensi. Edente Thoma Erpenio, Leiden, in Typographia Erpeniana Linguarum Orientalium.

Bible. 1657. Biblia Polyglotta. Bibliorum Sacrorum Tomus Quintus: sive Novum D. N. Jesu Christi Testamentum, 6 vols, London: Brianus Waltonus/Thomas Roycroft.

Bible. 1727. Al- ${ }^{c}$ ahd al-jadıd li-rabbinā Yas $\bar{u}^{c}$ al-Masīh, trans. Salomon Negri. London: SPCK. 
Bible. 1822/1671. Kitāb al-muqaddas al-muštamil ${ }^{c}$ alā kitāb al- ${ }^{c}$ ahd al${ }^{c}$ atīq al-mawjūda fì-l- ${ }^{\circ}$ aṣl al- ${ }^{\circ} i b r a ̄ n \bar{~} w a-{ }^{\circ}$ aydan kitāb al- ${ }^{c}$ ahd al-jadīd li-rabbinā Yāsū $\bar{u}^{c}$ al-Masīh... ${ }^{c}$ ala al-naškha al-mațbu $\bar{u}^{c}$ a fi-rūmiyya al${ }^{\circ} a z m \bar{a}$ sanat 1671 li-manfacat al-kanā is al-šarqiyya. London: Richard Watts.

Bible. 1979. Syriac Bible (title in Syriac). London: United Bible Societies.

Bible. 1983/1857. Kutub al-muqaddasa, wa-hiya kutub al- ${ }^{c}$ ahd al- ${ }^{c} a t \bar{q}$, trans. Fāris al-Shidyāq. Țarābulus: Maktabat al-sā̄ih.

Bible. 1991/1865. Al-Kitāb al-muqaddas ${ }^{\circ}$ ay kitāb al- ${ }^{c}$ ahd al-qadīm wal- ${ }^{c}$ ahd al-jadīd. Beirut: Dār al-kitāb al-muqaddas fī-l-sharq al- ${ }^{\circ}$ awsaṭ.

Bible. 1992/1878. Al-Kitāb al-muqaddas. Beirut: Dār al-kitāb almuqaddas fī-l-sharq al- ${ }^{\circ}$ awsaț.

BNM cod. 4971 (Bible manuscript). Madrid: Biblioteca Nacional.

Bocthor, Ellious. 1828-29. Dictionnaire français-arabe. Revue et augmenté par A. Caussin de Perceval. Paris: Firmin Didot.

al-Bustānī, Buṭus. n.d./1870. Kitāb muhīṭ al-muhịṭ. Qāmūs muțawwal lil-lugat al- ${ }^{c}$ arabiyya. Beirut: Maktabat Lubnān.

Carter, M. G., (ed.) 1981. Arab Linguistics. An Introductory Classical Text with Translation and Notes. Amsterdam: John Benjamins B.V.

Carter, M. G. 2001. A Missing Link between Law and Grammar. The intișār of Ibn Wallād, Arabica 48/1: 51-65.

Doniach, N.S., ed. 1982. The Concise Oxford English-Arabic Dicitionary of Current Usage. Oxford: Oxford University Press.

Freytag, Georg Wilhelm. 1835. Lexicon Arabico-Latinum, 4 vols, Halis Saxonum: C.A. Schwetschke et filium.

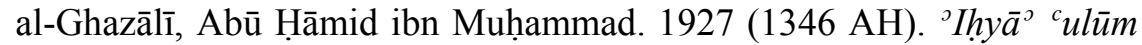
al-dīn. Cairo: Mațba ${ }^{c}$ at Muștafāa al-Bābī al-Halabī.

al-Ghazālī, Abū Ḥāmid Muḥammad ibn Muhammad. 1950. Bidāyat alhidāyat fi-l- ${ }^{\circ} \bar{a} d \bar{a} b$ wa-l- ${ }^{\circ} a k h l \bar{a} q$ wa-l-tașawwuf. Cairo: Maṭba ${ }^{\mathrm{c}}$ at Muștafã al-Bābī al-Ḥalabī.

Gibson, Margaret Dunlop. 1894. An Arabic Version of the Epistles of St Paul to the Romans, Corinthians, Galatians with Part of the Epistle to the Ephesians from a Ninth Century MS in the Convent of St Catharine on Mount Sinai, vol. II, Studia Sinaitica. London: C. J. Clay and Sons/Cambridge University Press.

Gibson, Margaret Dunlop. 1899. An Arabic Version of the Acts of the Apostles and the Seven Catholic Epistles from an Eighth or Ninth Century Ms. in the Convent of St. Catharine on Mount Sinai., vol. 7, Studia Sinaitica. London: C. J. Clay and Sons/Cambridge University Press. 
Graf, Georg. 1975-77/1944-53. Geschichte der christlichen arabischen Literatur, 5 vols, Rome: Studi e testi.

Humbert, Jean. 1838. Guide de la conversation arabe, ou vocabulaire français-arabe. Gèneve: J. Kessmann.

Kazimirski, A. de Biberstein. 1875. Dictionnaire arabe-français. 4 vols, Cairo: Revu et Corrigé par Ibed Gallab.

van Koningsveld, P. Sj. 1977. The Latin-Arabic Glossary of the Leiden University Library. A Contribution to the Study of Mozarabic Manuscripts and Literature. Leiden: New Rhine Publishers.

Kraemer, Joel L. 1986. Humanism in the Renaissance of Islam. Leiden: E. J. Brill.

Lane, William. 1874. An Arabic-English Lexicon. 8 vols, London: Williams and Norgate.

Leirvik, Oddbjørn. 2006. Human Conscience and Muslim-Christian Relations. Modern Egyptian Thinkers on al-ḍamīr. London: Routledge 2006

Leirvik, Oddbjørn. 2008. Muhammad, Christ and Modern Consciences, Studies in Interreligious Dialogue 2, 129-152.

Ibn Manẓūr. 1955. Lisān al- ${ }^{c}$ arab. 15 vols, Beirut: Dār Șādir/Dār Bayrūt.

Margoliouth, D. S. 1964/1911. 'Conscience (Muslim)', Encyclopcedia of Religion and Ethics, ed. J. Hastings. Edinburgh: T. and T. Clark

Massignon, Louis. 1954. Essai sur les origines du lexique technique de la mystique Musulmane. Paris: Librairie Philosophique J. Vrin.

Metzger, Bruce M. 1977. The Early Versions of the New Testament. Their Origin, Transmission, and Limitations. Oxford: Clarendon Press

al-Muhāsibī, Abū ${ }^{c}$ Abd Allāh Ḥārith ibn Asad. 1940. Kitāb al-ric āya lihuqūq Allāh, ed. Margareth Smith. London: Luzac.

Nwyia, Paul. 1968. Le Tafsīr mystique attribué à Gacfar Șādiq. Édition critique, Mélanges de 1'Université Saint-Joseph, 43/4. Beyrouth: Imprimerie Catholique.

Raphelengius, F. 1613. Lexicon Arabicum. Leiden: Ex officina auctoris.

Saadeh, Khalil. 1911. Saadeh's Dictionary. Cairo: Husny Bey Yeken.

Șalībā, Jamīl. 1971. Al-Mucjam al-falsafí. Beirut: Dār al-kitāb al-lubnān̄̄.

Seybold, Christianus Fredericus. 1900. Glossarium Latin-Arabicum. Ex unico qui exstat codice Leidensi undecimo saeculo in Hispania conscripto. Berolini: in Aedibus Aemilii Felber.

Spiro, Socrates. 1974/1897. An English-Arabic Dictionary of the Colloquial Arabic of Egypt. Beirut: Librairie du Liban.

Spiro, Socrates. 1980/1895. An Arabic-English Dictionary of the Colloquial Arabic of Egypt. Beirut: Librarie du Liban. 
Stenij, Edv. 1901. Die altarabische Übersetzung der Briefe an die Hebräer, an die Römer und an die Corinther aus einem in St. Petersburg befindlichen Codex Tischendorfs vom Jahre 892 n. Chr. Helsingfors: Frenkellska Tryckeri Aktiebolaget.

Staal, Harvey. 1983-1984. Mt. Sinai Arabic Codex 151. I: Pauline Epistles. II: Acts of the Apostles, Catholic Epistles. 4 vols, Corpus Scriptorum Christianorum Orientalum, vol. 453. Scriptores Arabici, Tom. 41. Lovanii: E. Peeters.

Thompson, John A. 1955. The Origin and Nature of the Chief Printed Arabic Bibles, parts I-IV. The Bible Translator 4:2-12, 51-5, 98-105, 146-50.

Tisdall, W. St. Clair. 1906. The Religion of the Crescent. London: SPCK.

Wehr, Hans. 1979. Arabic-English Dictionary. The Hans Wehr Dictionary of Modern Written Arabic, ed. J. M. Cowan. 4th ed. Ithaca, N.Y.: Spoken Language Services.

al-Zabīdī. 1888 (1306 AH). Tāj al- ${ }^{c}$ arūs min jawāhir al-qāmūs. Cairo: al-mațba ${ }^{c}$ a al-khayriyya. 